\title{
Genetic diversity and relationship of chicory (Cichorium intybus L.) using sequence-related amplified polymorphism markers
}

\author{
X.Y. Liang, ${ }^{1,2}$, X.Q. Zhang', S.Q. Bai ${ }^{3}$, L.K. Huang', X.M. Luo ${ }^{2}$, Y. Ji ${ }^{1,2}$ \\ and L.F. Jiang ${ }^{2}$ \\ ${ }^{1}$ Sichuan Animal Science Academy, Chengdu, China \\ ${ }^{2}$ Department of Grassland Science, Animal Science and Technology College, \\ Sichuan Agricultural University, Ya'an, China \\ ${ }^{3}$ Sichuan Academy of Grassland Sciences, Chengdu, China \\ Corresponding author: X.Q. Zhang \\ E-mail: zhangxq8@hotmail.com
}

Genet. Mol. Res. 13 (3): 7736-7746 (2014)

Received July 22, 2013

Accepted January 3, 2014

Published September 26, 2014

DOI http://dx.doi.org/10.4238/2014.September.26.11

ABSTRACT Chicory is a crop with economically important roles
and is cultivated worldwide. The genetic diversity and relationship
of 80 accessions of chicories and endives were evaluated by
sequence-related amplified polymorphism (SRAP) markers to
provide a theoretical basis for future breeding programs in China.
The polymorphic rate was $96.83 \%$, and the average polymorphic
information content was 0.323 , suggesting the rich genetic diversity
of chicory. The genetic diversity degree of chicory was higher $\left(G_{\mathrm{S}}\right.$
$=0.677)$ than that of endive $\left(G_{\mathrm{S}}=0.701\right)$. The accessions with the
highest genetic diversity (effective number of alleles, $N_{\mathrm{E}}=1.609$;
Nei's genetic diversity, $H=0.372 ;$ Shannon information index, $I=$
$0.556)$ were from Italy. The richest genetic diversity was revealed
in a chicory line $(N=1.478, H=0.289, I=0.443)$ among the
E 
3 types (line, wild, and cultivar). The chicory genetic structure of 8 geographical groups showed that the genetic differentiation coefficient $\left(G_{\mathrm{ST}}\right)$ was $14.20 \%$ and the number of immigrants per generation $\left(N_{\mathrm{m}}\right)$ was 3.020 . A $G_{\text {ST }}$ of $6.80 \%$ and an $N_{\mathrm{m}}$ of 6.853 were obtained from different types. This observation suggests that these chicory lines, especially those from the Mediterranean region, have potential for providing rich genetic resources for further breeding programs, that the chicory genetic structure among different countries obviously differs with a certain amount of gene flow, and that SRAP markers could be applied to analyze genetic relationships and classifications of Cichorium intybus and C. endivia.

Key words: Chicory; Cluster analysis; Genetic diversity; Genetic relationship; Sequence-related amplified polymorphism

\section{INTRODUCTION}

Chicory (Cichorium intybus; Asteraceae) is a diploid $(2 \mathrm{n}=18)$ and self-incompatible taproot perennial herb plant that is distributed in temperate and semi-arid regions of the world (Kiers et al., 2000; Hauser et al., 2012). It is widely cultivated as forage, vegetables, coffee substitutes, and traditional herbal medicine. Therefore, it is considered to be an important economic plant with extreme potential for future development (Bais and Ravishankar, 2001; de Kraker et al., 2001; Sulas, 2004; Nandagopal and Kumari, 2007). As forage, chicory is rich in nutrition, yields, palatability, digestibility, resistance to adversity, and pest resistance (de Kraker et al., 2002; Sulas, 2004; Ivarsson et al., 2011). Research has shown that the nutrition of chicory is virtually equivalent to and even surpasses some varieties of alfalfa (Sulas, 2004).

Compared with other animal husbandry in developed countries such as Italy, New Zealand, and Australia, forage chicory cultivated in China has a rather short history that began in the 1980s. Currently, there are no registered chicory varieties with independent intellectual property rights in China, and only 3 introduced forage chicory varieties are legally registered by Chinese authority. However, forage chicory planting areas have been expanding year by year, and the planting area of only one cultivar, Commander, reached 2600 ha in China in 2012. Some chicory varieties introduced are poor in adaptability to the local environment, which limits the improvement of yield and quality. Therefore, it is urgent to breed high-quality and high-yield forage chicory varieties. In recent years, a large number of chicory lines have been introduced from abroad for forage. The level of genetic diversity, genetic relationships, and genetic distances among and within chicory are unclear but would be of great interest for forage chicory breeding programs in China.

Molecular markers could be used to identify genetic relationships to help determine crop crossbreeding combinations of parents and the ideal traits in hybrid progeny (Ali et al., 2008). Considering the limited morphological traits and isozymes to identify genetic variations of chicory, molecular markers can be used to research the genetic variation of chicory (Kiers et al., 2000). Sequence-related amplified polymorphism (SRAP) markers are a newly developed molecular maker technology based on polymerase chain reaction (PCR). Compared 
with other molecular marker technologies, SRAP combines the advantages of simplicity, reliability, reasonable throughput rate, codominance, clear and high-intensity bands that rarely overlap, cost effectiveness, and multi-loci and multi-allele applications, giving this technique potential to be efficient for genetic diversity, gene mapping, and fingerprinting analyses ( $\mathrm{Li}$ and Quiros, 2001; Aneja et al., 2012). SRAP has been successfully applied in genetic diversity analysis, cultivar identification, genetic linkage map construction, and gene cloning for many plants (Aneja et al., 2012).

The aims of this study were to evaluate the molecular variation and structure of this population to explore the effectiveness for SRAP to analyze and identify $C$. intybus and $C$. endivia, and to determine whether there is a relatively high genetic diversity within chicory for further breeding programs.

\section{MATERIAL AND METHODS}

\section{Plant materials}

Eighty accessions of Cichorium consisted of 2 species, C. intybus and C. endivia. Seventy-five accessions were kindly provided by the National Plant Germplasm System and originated from 15 countries, which included 4 accessions of endive, and the other 5 accessions were from China. The detailed information on the type of materials, origins, and serial numbers is listed in Table 1. All materials were cultivated in the Regional Forage Experimental Station of China in Hongya County, Sichuan Province, China.

\section{DNA extraction}

Young leaves of 15 monoclonal chicory with similar phenotypes at the 5- or 6-leaf stage were equally selected and mixed to obtain $100 \mathrm{mg}$ to extract general DNA utilizing the cetyltrimethylammonium bromide method. The concentration and purity of the DNA were evaluated by $0.8 \%$ agarose gel electrophoresis and ultraviolet spectrophotometry. The working solutions of DNA were then diluted to $10 \mathrm{ng} / \mu \mathrm{L}$ and stored at $-20^{\circ} \mathrm{C}$.

\section{Primer selection and PCR amplification}

Sixty-six primer pairs (Budak et al., 2004; Guo and Luo, 2006) were used to screen by SRAP markers. Thirty-six polymorphic primer pairs that generated clear and reproducible banding patterns were selected for further analysis. The PCR system was $15 \mu \mathrm{L}$, which included $1 \mu \mathrm{L}$ DNA, $0.3 \mu \mathrm{L} 2.5 \mathrm{U} / \mu \mathrm{L}$ Taq DNA polymerase, $0.8 \mu \mathrm{L} 10 \mathrm{mM}$ forward primer, $0.8 \mu \mathrm{L} 10 \mathrm{mM}$ reverse primer, $2 \mu \mathrm{L}$ 10X PCR buffer, $2 \mu \mathrm{L} 25 \mathrm{mM} \mathrm{Mg}^{2+}, 2.4 \mu \mathrm{L} 2.5 \mathrm{mM}$ dNTPs, and $5.7 \mu \mathrm{L}$ sterile water. The PCR was conducted under the following conditions: 4 min at $94^{\circ} \mathrm{C} ; 5$ cycles of $94^{\circ} \mathrm{C}$ for $1 \mathrm{~min}, 35^{\circ} \mathrm{C}$ for $1 \mathrm{~min}$, and $72^{\circ} \mathrm{C}$ for $1 \mathrm{~min} ; 35$ cycles of $94^{\circ} \mathrm{C}$ for $1 \mathrm{~min}, 50^{\circ} \mathrm{C}$ for $1 \mathrm{~min}$, and $72^{\circ} \mathrm{C}$ for $1 \mathrm{~min}$; extension of $10 \mathrm{~min}$ at $72^{\circ} \mathrm{C}$; and a final storage at $4^{\circ} \mathrm{C}$. PCR amplification products were visualized on $6.0 \%$ polyacrylamide gels by electrophoresis in $1 \mathrm{X}$ Tris, borate, and ethylenediaminetetraacetic acid electrophoresis buffer solution at $400 \mathrm{~V}$ for $2 \mathrm{~h}$. The gel product was silver stained and photographed by a digital camera. 


\begin{tabular}{|c|c|c|c|c|c|c|c|}
\hline Accession No. & Species & Origin & $\begin{array}{l}\text { Material } \\
\text { type }\end{array}$ & $\begin{array}{l}\text { Accession } \\
\text { No. }\end{array}$ & Species & Origin & $\begin{array}{l}\text { Material } \\
\text { type }\end{array}$ \\
\hline PI651889 & C.endivia $\mathrm{L}$ & North Holland, Netherlands & Cultivar & PI503594 & C.endivia $\mathrm{L}$. & Peloponnese, Greece & Line \\
\hline PI503588 & C.endivia $\mathrm{L}$. & Calabria, Italy & Line & $\mathrm{J}-2$ & C.endivia $\mathrm{L}$. & China & Line \\
\hline PI503599 & C.endivia $\mathrm{L}$. & Calabria, Italy & Line & PI651999 & C.intybus $\mathrm{L}$. & Piedmont, Italy & Line \\
\hline PI651946 & C.intybus $\mathrm{L}$. & North Holland, Netherlands & Line & PI652035 & C.intybus $\mathrm{L}$. & Veneto, Italy & Cultivar \\
\hline PI651947 & C.intybus $\mathrm{L}$. & North Holland, Netherlands & Line & PI652037 & C.intybus $\mathrm{L}$. & Veneto, Italy & Cultivar \\
\hline PI651990 & C.intybus $\mathrm{L}$. & North Holland, Netherlands & Line & PI652038 & C.intybus $\mathrm{L}$. & Veneto, Italy & Cultivar \\
\hline PI651992 & C.intybus $\mathrm{L}$. & North Holland, Netherlands & Line & PI652039 & C.intybus $\mathrm{L}$. & Veneto, Italy & Cultivar \\
\hline PI651950 & C.intybus $\mathrm{L}$. & South Holland, Netherlands & Line & PI652040 & C.intybus $\mathrm{L}$. & Veneto, Italy & Cultivar \\
\hline PI651951 & C.intybus $\mathrm{L}$. & South Holland, Netherlands & Line & PI652041 & C.intybus $\mathrm{L}$. & Trentino-Alto Adige, Italy & Cultivar \\
\hline PI651984 & C.intybus $\mathrm{L}$. & South Holland, Netherlands & Line & PI652045 & C.intybus $\mathrm{L}$. & Trentino-Alto Adige, Italy & Cultivar \\
\hline PI652005 & C.intybus $\mathrm{L}$. & South Holland, Netherlands & Line & PI652046 & C.intybus $\mathrm{L}$. & Trentino-Alto Adige, Italy & Cultivar \\
\hline PI651969 & C.intybus $\mathrm{L}$. & Limburg, Netherlands & Line & PI652047 & C.intybus $\mathrm{L}$. & Trentino-Alto Adige, Italy & Cultivar \\
\hline PI651971 & C.intybus $\mathrm{L}$. & Limburg, Netherlands & Line & PI652042 & C.intybus $\mathrm{L}$. & Lombardy, Italy & Line \\
\hline PI651986 & C.intybus L. & Limburg, Netherlands & Line & PI255565 & C.intybus $\mathrm{L}$. & Friuli-Venezia, Italy & Cultivar \\
\hline PI651987 & C.intybus $\mathrm{L}$. & Limburg, Netherlands & Line & PI652043 & C.intybus L. & Emilia-Romagna, Italy & Cultivar \\
\hline PI651930 & C.intybus $\mathrm{L}$. & USA & Line & PI652044 & C.intybus $\mathrm{L}$. & Emilia-Romagna, Italy & Cultivar \\
\hline NSL6407 & C.intybus $\mathrm{L}$. & California, USA & Cultivar & PI652007 & C.intybus $\mathrm{L}$. & Bydgoszcz, Poland & Wild \\
\hline NSL69921 & C.intybus L. & Pennsylvania, USA & Cultivar & PI652008 & C.intybus $\mathrm{L}$. & Suwalki, Poland & Wild \\
\hline PI651954 & C.intybus $\mathrm{L}$. & Germany & Cultivar & PI652009 & C.intybus $\mathrm{L}$. & Zamosc, Poland & Wild \\
\hline PI651931 & C.intybus $\mathrm{L}$. & Maine-et-Loire, France & Line & PI652025 & C.intybus $\mathrm{L}$. & Lublin, Poland & Wild \\
\hline PI651932 & C.intybus $\mathrm{L}$. & Essonne, France & Line & PI652051 & C.intybus L. & Przemysl, Poland & Wild \\
\hline PI651936 & C.intybus $\mathrm{L}$. & Essonne, France & Line & PI652019 & C.intybus $\mathrm{L}$. & Switzerland & Wild \\
\hline PI651940 & C.intybus $\mathrm{L}$. & Essonne, France & Line & PI652020 & C.intybus L. & Hungary & Wild \\
\hline PI651949 & C.intybus $\mathrm{L}$. & Essonne, France & Line & PI652021 & C.intybus L. & Hungary & Wild \\
\hline PI651975 & C.intybus $\mathrm{L}$. & Essonne, France & Line & PI652022 & C.intybus $\mathrm{L}$. & Hungary & Wild \\
\hline PI652015 & C.intybus $\mathrm{L}$. & Yvelines, France & Cultivar & PI531291 & C.intybus $\mathrm{L}$. & Hungary & Wild \\
\hline PI652017 & C.intybus $\mathrm{L}$. & Yvelines, France & Cultivar & PI531292 & C.intybus L. & Hungary & Wild \\
\hline PI652018 & C.intybus $\mathrm{L}$. & Yvelines, France & Cultivar & PI652026 & C.intybus $\mathrm{L}$. & Mazandaran, Iran & Wild \\
\hline PI393816 & C.intybus $\mathrm{L}$. & France & Line & PI652028 & C.intybus $\mathrm{L}$. & Krasnodar, Russian Federation & Wild \\
\hline PI393822 & C.intybus $\mathrm{L}$. & France & Line & PI652030 & C.intybus $\mathrm{L}$. & Former Serbia and Montenegro & Wild \\
\hline PI261776 & C.intybus L. & Ville-de-Paris, France & Line & PI652033 & C.intybus $\mathrm{L}$. & Coimbra, Portugal & Wild \\
\hline PI651955 & C.intybus $\mathrm{L}$. & Baden-Wurttemberg, Germany & Line & PI652050 & C.intybus $\mathrm{L}$. & Coimbra, Portugal & Wild \\
\hline PI652023 & C.intybus $\mathrm{L}$. & Saxony-Anhalt, Germany & Wild & PI393821 & C.intybus $\mathrm{L}$. & Belgium & Line \\
\hline PI652024 & C.intybus $\mathrm{L}$. & Saxony-Anhalt, Germany & Wild & PI432336 & C.intybus $\mathrm{L}$. & Cyprus & Line \\
\hline PI504468 & C.intybus $\mathrm{L}$. & Germany & Line & PI491197 & C.intybus $\mathrm{L}$. & Greece & Line \\
\hline PI651957 & C.intybus $\mathrm{L}$. & Italy & Line & A-1 & C.intybus $\mathrm{L}$. & China & Line \\
\hline PI651958 & C.intybus $\mathrm{L}$. & Italy & Line & A-2 & C.intybus $\mathrm{L}$. & China & Wild \\
\hline PI652048 & C.intybus $\mathrm{L}$. & Italy & Cultivar & $\mathrm{P}-2$ & C.intybus $\mathrm{L}$. & China & Line \\
\hline PI651961 & C.intybus $\mathrm{L}$. & Piedmont, Italy & Line & $\mathrm{J}-1$ & C.intybus $\mathrm{L}$. & China & Line \\
\hline PI651995 & C.intybus $\mathrm{L}$. & Piedmont, Italy & Line & & & & \\
\hline PI651997 & C.intybus L. & Piedmont, Italy & Line & & & & \\
\hline
\end{tabular}

\section{Data analysis}

The raw data matrix was manually scored in accordance with band presence (1) and absence (0). The total number of bands, number of polymorphic bands, polymorphic rate, and polymorphism information content (PIC) (Roldán-Ruiz et al., 2000) were calculated. The NTsys-pc 2.10e software was used to calculate the Jaccard similarity coefficient using the SimQual program. A similarity matrix was calculated for the intraspecific genetic similarity coefficient $\left(G_{\mathrm{S}}\right)$. A clustering dendrogram was obtained by unweighted pair-group method using arithmetic averages (UPGMA) of the SHAN program through the Treeplot module. PopGen32 (Nei, 1973) was used to calculate genetic diversity indexes and the genetic structure of chicory groups, including the group Shannon information index $(I)$, observed number of alleles, effective number of alleles $\left(N_{\mathrm{E}}\right)$, Nei's gene diversity $(H)$, number of polymorphic loci, percentage of polymorphic loci, total genetic diversity, genetic diversity within popula- 
tions, Nei's genetic differentiation between populations $\left(G_{\mathrm{ST}}\right)$, and number of immigrants per generation $\left(N_{\mathrm{m}}, N_{\mathrm{m}}=0.5 \times\left(1-G_{\mathrm{ST}}\right) / G_{\mathrm{ST}}\right)$.

\section{RESULTS}

\section{Chicory polymorphism}

A total of 36 primer combinations were used to evaluate the genetic diversity of the 75 chicory accessions. The total bands, polymorphic bands, polymorphic rates, and PIC values per primer pair were presented in Table 2 . These 36 primer combinations totally produced 985 clear bands with a mean of 27.4 and a range from 15 to 41 bands per primer combination, including 951 polymorphic bands with a polymorphic rate that ranged from 86.67 to $100 \%$ and had a mean of $96.83 \%$. The high genetic diversity of the materials studied was demonstrated. Each primer combination produced an average of 26.4 polymorphic bands. The PIC ranged from $0.211(\mathrm{me} 1+\mathrm{em} 1)$ to $0.376(\mathrm{me} 7+\mathrm{em} 7)$ and had a mean of 0.323 .

\begin{tabular}{|c|c|c|c|c|}
\hline Primer combination & $\begin{array}{l}\text { Total number of } \\
\text { bands }(\mathrm{N})\end{array}$ & $\begin{array}{l}\text { Polymorphism } \\
\text { bands (PB) }\end{array}$ & $\begin{array}{l}\text { Polymorphic } \\
\text { rate }(\mathrm{P})(\%)\end{array}$ & $\begin{array}{l}\text { Polymorphism information } \\
\text { content (PIC) }\end{array}$ \\
\hline $\mathrm{me} 1+\mathrm{em} 1$ & 15 & 15 & 100 & 0.211 \\
\hline $\mathrm{me} 1+\mathrm{em} 2$ & 19 & 18 & 94.74 & 0.278 \\
\hline $\mathrm{me} 1+\mathrm{em} 3$ & 32 & 31 & 96.88 & 0.370 \\
\hline $\mathrm{me} 1+\mathrm{em} 12$ & 26 & 26 & 100 & 0.367 \\
\hline $\mathrm{me} 1+\mathrm{em} 10$ & 18 & 18 & 100 & 0.279 \\
\hline $\mathrm{me} 1+\mathrm{em} 13$ & 23 & 21 & 91.30 & 0.297 \\
\hline $\mathrm{me} 2+\mathrm{em} 2$ & 24 & 24 & 100 & 0.368 \\
\hline $\mathrm{me} 2+\mathrm{em} 3$ & 28 & 28 & 100 & 0.362 \\
\hline $\mathrm{me} 2+\mathrm{em} 7$ & 25 & 23 & 92 & 0.345 \\
\hline me $2+$ em 15 & 24 & 23 & 95.83 & 0.307 \\
\hline me $2+$ em17 & 23 & 20 & 86.96 & 0.337 \\
\hline me $2+$ em 18 & 28 & 28 & 100 & 0.349 \\
\hline $\mathrm{me} 3+\mathrm{em} 13$ & 32 & 32 & 100 & 0.312 \\
\hline me3 + em15 & 23 & 20 & 100 & 0.249 \\
\hline me3 + em17 & 29 & 29 & 100 & 0.351 \\
\hline me4 + em2 & 23 & 22 & 95.65 & 0.290 \\
\hline me5 + em9 & 30 & 29 & 96.67 & 0.303 \\
\hline $\mathrm{me} 7+\mathrm{em} 3$ & 30 & 26 & 86.67 & 0.293 \\
\hline $\mathrm{me} 7+\mathrm{em} 4$ & 24 & 22 & 91.67 & 0.373 \\
\hline $\mathrm{me} 7+\mathrm{em} 7$ & 33 & 32 & 96.97 & 0.376 \\
\hline me $8+$ em 4 & 30 & 30 & 100 & 0.310 \\
\hline me8 + em13 & 24 & 24 & 100 & 0.248 \\
\hline me8 + em16 & 31 & 28 & 90.32 & 0.281 \\
\hline $\mathrm{me} 9+\mathrm{em} 7$ & 30 & 29 & 96.67 & 0.372 \\
\hline me $9+$ em 9 & 34 & 32 & 94.12 & 0.309 \\
\hline me10+ em4 & 26 & 25 & 96.15 & 0.316 \\
\hline me10+ em6 & 34 & 33 & 97.06 & 0.342 \\
\hline me10 + em 9 & 33 & 32 & 96.97 & 0.338 \\
\hline me10 + em16 & 28 & 28 & 100 & 0.370 \\
\hline me10 + em5 & 21 & 21 & 100 & 0.320 \\
\hline me11 + em4 & 27 & 26 & 96.30 & 0.294 \\
\hline me11 + em8 & 27 & 26 & 96.30 & 0.337 \\
\hline me11 + em11 & 30 & 29 & 96.67 & 0.357 \\
\hline me11 + em16 & 32 & 32 & 100 & 0.316 \\
\hline me12 + em4 & 28 & 28 & 100 & 0.325 \\
\hline me12+em19 & 41 & 41 & 100 & 0.368 \\
\hline Total & 985 & 951 & & \\
\hline Mean & 27.4 & 26.4 & 96.83 & 0.323 \\
\hline
\end{tabular}

Genetics and Molecular Research 13 (3): 7736-7746 (2014) 


\section{Genetic variation based on SRAP markers}

Analysis of the $G_{\mathrm{S}}$ among 80 accessions of tested materials showed a rich genetic diversity and far relationship between intraspecific and interspecific samples (data not shown). The in-pair $G_{\mathrm{S}}$ values of the 75 chicory accessions ranged from 0.519 to 0.903 and had a mean of 0.677. The $G_{\mathrm{S}}$ of PI 652005, which originated from South Holland of the Netherlands, and $\mathrm{J}$-1, which originated from China, was the lowest, which indicated the farthest genetic relationship. The $G_{\mathrm{S}}$ values of the 5 accessions of endive ranged from 0.565 to 0.843 and had a mean of 0.701 . Compared with the $G_{\mathrm{S}}$ values of interspecific samples, the average $G_{\mathrm{S}}$ value of endive was higher than that of chicory, which indicated that the genetic diversity of chicory was higher than that of endive.

At least 3 accessions of chicory from original countries were divided into 8 geographic groups to determine the genetic diversity based on structure analysis. The Shannon index varied between 0 and 1 , where a number closer to 1 indicated that the genetic diversity was increasingly abundant (Estopa et al., 2006). Among the 8 groups, the richest genetic diversity was observed in Italy $\left(N_{\mathrm{E}}=1.609, H=0.372, I=0.556\right)$, followed by France, and the last was the United States (Table 3). Based on the genetic diversity analyses for 3 types of materials (line, wild, and cultivar), the genetic differences among the 3 types of materials were large, and lines had the richest genetic diversity $\left(N_{\mathrm{E}}=1.478, H=0.289, I=0.443\right)$. However, wild materials had the lowest genetic diversity $\left(N_{\mathrm{E}}=1.378, H=0.232, I=0.359\right)$, showing that wild materials had genetic stability and a narrow genetic basis (Table 3 ). In addition, Nei's analysis for the genetic structure of the 8 geographical groupings showed that the average genetic diversity within a group was the richest $(0.340)$ with a genetic differentiation coefficient $\left(G_{\mathrm{ST}}\right)$ of $14.20 \%$ and $N_{\mathrm{m}}$ of 3.020 , suggesting that the chicory genetic structure among different countries obviously differed with a certain amount of gene flow (Table 4). The $G_{\mathrm{ST}}$ of $6.80 \%$ and $N_{\mathrm{m}}$ of 6.853 were used to analyze the genetic structure of 3 types of materials in a population, which indicated that the genetic structure among different types of materials has a small, frequent gene flow (Table 4).

\begin{tabular}{|c|c|c|c|c|c|c|c|}
\hline Group & $\mathrm{N}$ & $\mathrm{K}$ & $\mathrm{P}(\%)$ & $N_{\mathrm{A}}$ & $N_{\mathrm{E}}$ & $H$ & $I$ \\
\hline \multicolumn{8}{|l|}{ Country } \\
\hline Holland & 12 & 984 & 99.80 & $1.999(0.045)$ & $1.535(0.222)$ & $0.335(0.099)$ & $0.511(0.117)$ \\
\hline France & 12 & 984 & 99.80 & $1.999(0.045)$ & $1.588(0.227)$ & $0.357(0.097)$ & $0.537(0.115)$ \\
\hline Italy & 20 & 986 & 100.00 & $2.000(0.000)$ & $1.609(0.171)$ & $0.372(0.069)$ & $0.556(0.077)$ \\
\hline Germany & 5 & 936 & 94.93 & $1.949(0.220)$ & $1.607(0.294)$ & $0.354(0.134)$ & $0.525(0.172)$ \\
\hline Poland & 5 & 915 & 92.80 & $1.928(0.259)$ & $1.548(0.291)$ & $0.329(0.138)$ & $0.494(0.183)$ \\
\hline Hungary & 5 & 960 & 97.36 & $1.974(0.160)$ & $1.574(0.266)$ & $0.345(0.119)$ & $0.519(0.148)$ \\
\hline China & 4 & 842 & 85.40 & $1.854(0.353)$ & $1.559(0.340)$ & $0.323(0.166)$ & $0.479(0.227)$ \\
\hline America & 3 & 763 & 77.38 & $1.774(0.419)$ & $1.536(0.371)$ & $0.305(0.185)$ & $0.449(0.259)$ \\
\hline Mean & 66 & & & $2.000(0.000)$ & $1.630(0.106)$ & $0.384(0.040)$ & $0.572(0.044)$ \\
\hline \multicolumn{8}{|l|}{ Type } \\
\hline Cultivar & 19 & 832 & 84.38 & $1.844(0.363)$ & $1.425(0.348)$ & $0.255(0.179)$ & $0.391(0.244)$ \\
\hline Wild & 19 & 795 & 80.63 & $1.806(0.395)$ & $1.378(0.338)$ & $0.232(0.176)$ & $0.359(0.244)$ \\
\hline Line & 37 & 942 & 95.54 & $1.955(0.207)$ & $1.478(0.326)$ & $0.289(0.160)$ & $0.443(0.208)$ \\
\hline Mean & 75 & & & $1.959(0.197)$ & $1.463(0.317)$ & $0.283(0.155)$ & $0.437(0.203)$ \\
\hline
\end{tabular}

$\mathrm{N}$ = sample number; $\mathrm{K}=$ number of polymorphic loci; $\mathrm{P}=$ percentage of polymorphic loci; $N_{\mathrm{A}}=$ number of alleles; $N_{\mathrm{E}}=$ effective number of alleles; $H=$ Nei's gene diversity; $I=$ Shannon's information index. 


Table 4. Genetic structure of chicory from different grouping.
\begin{tabular}{lccccc}
\hline Groups & $\mathrm{N}$ & $H_{\mathrm{T}}$ & $H_{\mathrm{S}}$ & $G_{\mathrm{ST}}$ & $N_{\mathrm{m}}$ \\
\hline Country & 66 & 0.396 & 0.340 & $14.20 \%$ & 3.020 \\
Type & 75 & 0.278 & 0.259 & $6.80 \%$ & 6.853 \\
\hline $\mathrm{N}=$ sample number; $H_{\mathrm{T}}=$ total genetic diversity; $H_{\mathrm{S}}=$ genetic diversity & within populations; $G_{\mathrm{ST}}=$ genetic \\
differentiation coefficient; $N_{\mathrm{M}}=$ gene flow estimates.
\end{tabular}

\section{Genetic relationships revealed by clustering of SRAP markers}

The UPGMA tree generated from genetic distance coefficients grouped the 80 materials tested into 7 groups with a genetic similarity coefficient of 0.698 (Figure 1). The dendrogram showed that samples from the same country could mostly be clustered together, but clustering did not exactly follow geographic origins. In contrast, the 5 accessions of endive species were clustered in 2 groups. Cluster I contained PI 651889 (C. endivia). Cluster II contained 29 accessions of $C$. intybus; the first subgroup included 16 accessions originated from Italy, the Netherlands, France, and Germany except cultivars PI 652048 and PI 651954, and the second subgroup revealed a clear organization that included 13 accessions from Italy. Of the 19 wild chicories, 16 were grouped in cluster III; materials from Poland and Hungary showed a clear geographic grouping. Group IV comprised 23 accessions of chicory with diversified types. Most of the accessions from the Netherlands and France were clustered in the same subgroup, while other samples from various regions overlapped in distribution from the dendrogram. Two accessions from the USA were clustered separately in group V. Group VI contained 4 endive accessions, and 2 endives from Italy were placed in one subgroup, while 2 endives from Greece and China were clustered in another subgroup. PI 652050 from Portugal, PI 432336 from Cyprus, and A-1 and J-1 from China were clustered in group VII, and A-1 and J-1 were clustered in one subgroup.

\section{DISCUSSION}

\section{Effectiveness of SRAP markers to study genetic diversity and relationships in Cichorium}

Genetic differences evaluated using molecular markers will help to determine appropriate selection ratios and to maintain enough variation to select the breeding cycles (Azevedo et al., 2011). Based on our SRAP polymorphic analysis, chicory had a high level of genetic diversity compared with other species (Chang et al., 2012), and the higher level of sample polymorphism by SRAP was because of differences in the species, number of primers (Ullah et al., 2012), type of materials, number of samples, and PCR system. Additionally, SRAP molecular markers could be utilized to detect variations among and within populations of chicory, differentiate the 2 species of chicory and endive within the genus, and reveal the genetic relationship between species as effectively as amplified fragment length polymorphism (Kiers et al., 2000) and restriction fragment length polymorphism molecular markers (Vermeulen et al., 1994). It may be inferred that SRAP markers can be used for system classification studies in Cichorium, but further study is needed to identify interspecific relationships of other species in Cichorium. 


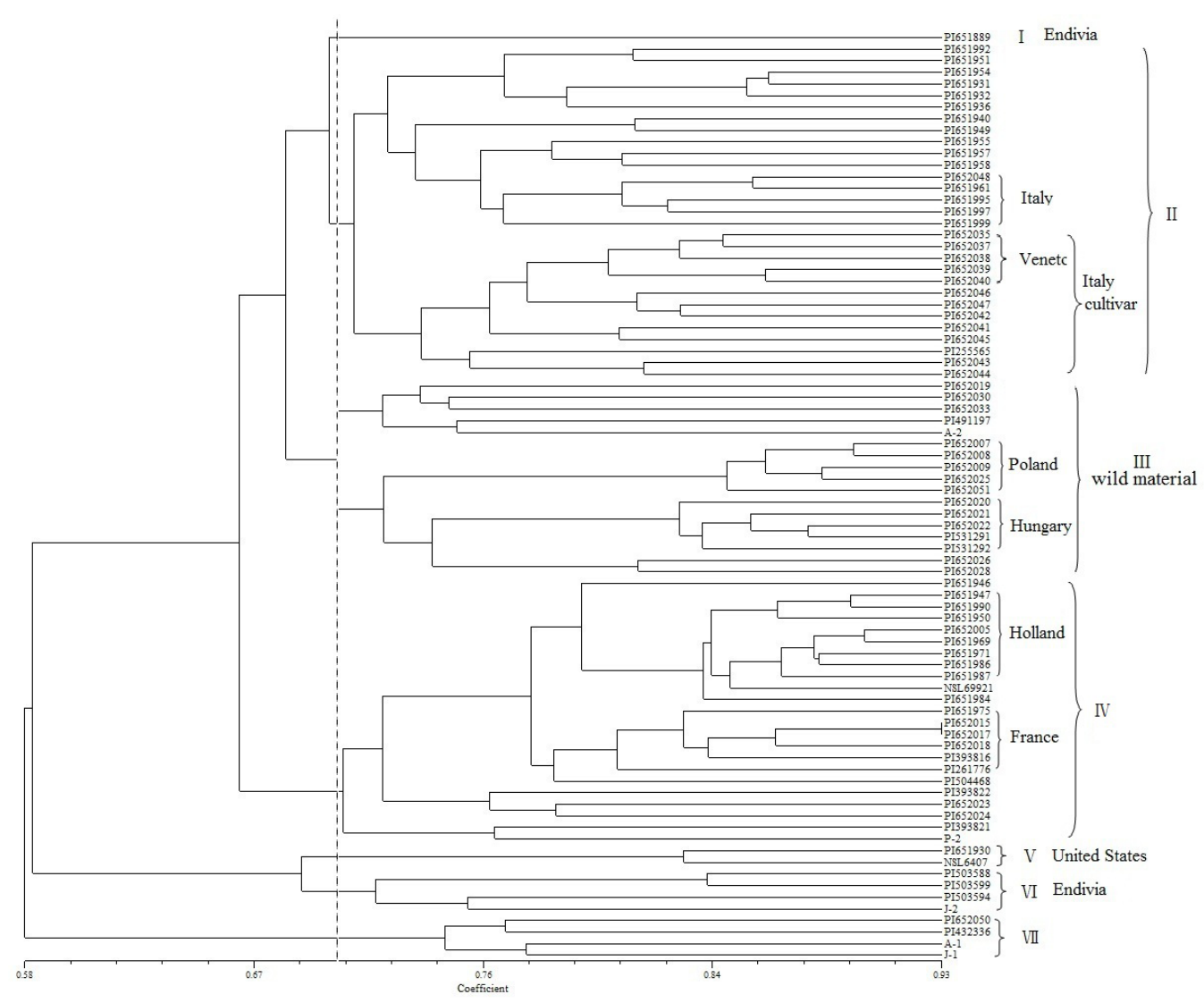

Figure 1. Unweighted pair-group method using arithmetic averages (UPGMA)-derived dendrogram of 80 accessions based on genetic identity (Nei, 1973). The accession designations refer to those listed in Table 1.

\section{Analysis of the genetic diversity of chicory and endive and its significance in breeding}

Chicory has accumulated a large amount of genetic variation, and it contains abundant genetic diversity, which is controlled by a number of factors including outcrossing mechanisms, environments, and natural and artificial selection (Kiær et al., 2009). The in-pair $G_{\mathrm{S}}$ mean value of the 75 chicory accessions was 0.677 in this study, while a high level of diversity was detected in the 2 species. This could be largely due to the observation that $C$. endivia is self-compatible, while $C$. intybus is self-incompatible (Kiers et al., 2000). In addition, this finding could also be caused by the morphological diversity of the 2 species: chicory contains 2 types of leaves and roots, but endive has only 1 leaf type (Lucchin et al., 2008). In addition, de Proft et al. (2003) suggested that negative characteristics probably appear as selection continues because of the narrow genetic basis of endive.

The genetic variation distribution is not random within populations, which are determined by the reproductive system, geographic distribution, effective scale of populations, pattern of reproduction, gene flow through the spread of pollen, and evolutionary factors that act 
on the genetic diversity (Azevedo et al., 2011). Among the 8 countries, the degree of genetic diversity of chicory from Italy was the highest. This was probably because Italy is one of the essential origins of chicory (Kiær et al., 2009) and these tested materials covered most of the material types, or because of the uneven number of tested samples from different countries. Therefore, it is necessary to protect the biodiversity of chicory germplasm and consider introducing more lines from regions with high genetic diversity for breeding programs. Of the 3 types, wild materials had the lowest genetic diversity level, indicating the narrow genetic background and the loss of genetic diversity; this result was different from other research results (Van Cutsem et al., 2003). However, a broader genetic basis and potential gene resources with resistances to biological and abiotic stresses can be obtained through utilizing wild varieties (Singh et al., 2008). Thus, we should study the resistance characteristics of wild materials further. The results of this research showed that the varieties had a low level of genetic variation, probably because modern breeding practices led to a significant decrease of genetic diversity in modern varieties (Martos et al., 2005). As intermediate breeding materials, lines of chicories had the highest genetic diversity probably because of the wide source, large size of the sample, numerous functions, and direct domestication from wild material or hybrids. This also suggests that these lines have potential to provide further gains from selection within a breeding program. The genetic diversity level of different populations of chicory is high based on the genetic structure analysis in this study, but the diversity level of the geographic groups is higher than that of the type groups. The genetic structure analysis for type groups also showed a high $N_{\mathrm{m}}(6.853)$ and low $G_{\mathrm{ST}}(6.80 \%)$. Therefore, frequent gene flow is an essential reason for the low genetic differentiation level among the materials of different types of chicory. However, more samples should be included to provide a more exact estimation of genetic distances (Moura and de Oliveira, 2012).

\section{Relationship between the clustering and geographic origin of Cichorium}

UPGMA was known to be the hierarchical method of producing dendrograms with the maximum cophenetic correlation (Bertini et al., 2006), and it was the most efficient method to represent dissimilarities among genotypes. Clustering analysis showed that 75 chicory accessions from different countries could mostly be clustered together in a dendrogram, but the clustering was not exactly consistent with geographic origins. Chicory germplasm that originated from Italy, Poland, Hungary, and other countries gathered separately in the same group according to the geographical origin as expected because of the geographical isolation. Especially, Italian varieties except PI652048 were clustered in the same group, suggesting that Italy contains a core germplasm; this result was similar to that obtained by Koch and Jung (1997). The reason for this may be the frequent gene penetration among different varieties that originated from Italy or mixed cultivation, which resulted in natural hybridization and natural gene penetration (Kiers et al., 1999; Kiær et al., 2009). However, genetic relationships based on molecular markers and pedigree information were not always consistent (Ali et al., 2008). Accessions from Germany, France, China, and other countries had a staggered distribution in the dendrogram. Sarwat et al. (2008) indicated that populations with geographic and genetic differences cannot be completely isolated, but they can exchange genetic information, probably because of similar climates (mainly continental and oceanic climates), geographic neighborhoods, difficult gene isolation, and frequent gene flow in the countries with materials by 
exchanging germplasms from different regions (Choudhary et al., 2012). China and Belgium are far apart and have large climate differences, but some of their chicories had close genetic relationships, probably because China introduced a large deal of chicory germplasm from Belgium since the 1980s. Most wild materials cluster together in a group, and a few cluster in other groups. This situation indicated the strong geographic distribution and wide ecological adaptability of chicory genotype through long-term natural selection. Meanwhile, this also suggests that gene penetration not only occurs between the domesticated materials but also spread to wild populations from the cultivated chicory (Sørensen et al., 2007).

\section{Relationship between chicory and endive based on clustering}

In addition, 5 accessions of endive were clustered separately in groups I and VI, indicating obvious genetic distance between the $C$. endivia and $C$. intybus. However, their distances were not very large. This was probably because natural hybridization can lead to a very close genetic relationship among populations of chicory and endive. Furthermore, artificial hybridization may cause gene flow and intraspecific and interspecific interpenetration. For example, variegated chicory is formed as a result of controlled or random crossbreeding between $C$. intybus var. foliosum and C. endivia var. latifolium (Biesiada and Tomczak, 2012), which indicated interspecific spontaneous gene flow. Therefore, out-crossing between C. intybus and C. endivia could be considered to promote the breeding success of the chicory breeding process.

\section{ACKNOWLEDGMENTS}

Research supported by the National "Twelfth Five-Year" Plan for Science \& Technology Support (\#2011BAD17B03), the earmarked fund for Modern Agro-industry Technology Research System (No. CARS-35-05), and Fund of Scientific Research Products Transforming for Research Institutes of Sichuan Province (\#2009090119). The authors thank the National Plant Germplasm System for kindly supplying the seeds.

\section{REFERENCES}

Ali ML, Rajewski JF, Baenziger PS, Gill KS, et al. (2008). Assessment of genetic diversity and relationship among a collection of US sweet sorghum germplasm by SSR markers. Mol. Breed. 21: 497-509.

Aneja B, Yadav NR, Chawla V and Yadav RC (2012). Sequence-related amplified polymorphism (SRAP) molecular marker system and its applications in crop improvement. Mol. Breed. 30: 1635-1648.

Azevedo AL, Costa PP, Machado MA, de Paula CM, et al. (2011). High degree of genetic diversity among genotypes of the forage grass Brachiaria ruziziensis (Poaceae) detected with ISSR markers. Genet. Mol. Res. 10: 3530-3538.

Bais HP and Ravishankar GA (2001). Cichorium intybus L. cultivation, processing, utility, value addition and biotechnology, with an emphasis on current status and future prospects. J. Sci. Food Agr. 81: 467-484.

Bertini CHCM, Schuster I, Sediyama T and Barros EG (2006). Characterization and genetic diversity analysis of cotton cultivars using microsatellites. Genet. Mol. Biol. 29: 321-329.

Biesiada A and Tomczak A (2012). Usability of different types and cultivars of salad chicory [Cichorium intybus L. var. foliosum (Hegi) Bish.] for spring cultivation. Acta Sci. Pol. Hortoru. 11: 193-204.

Budak H, Shearman RC, Parmaksiz I, Gaussoin RE, et al. (2004). Molecular characterization of Buffalograss germplasm using sequence-related amplified polymorphism markers. Theor. Appl. Genet. 108: 328-334.

Chang D, Yang FY, Yan JJ, Wu YQ, et al. (2012). SRAP analysis of genetic diversity of nine native populations of wild sugarcane, Saccharum spontaneum, from Sichuan, China. Genet. Mol. Res. 11: 1245-1253.

Choudhary P, Khanna SM, Jain PK, Bharadwaj C, et al. (2012). Genetic structure and diversity analysis of the primary 
gene pool of chickpea using SSR markers. Genet. Mol. Res. 11: 891-905.

de Kraker JW, Franssen MC, Dalm MC, de Groot A, et al. (2001). Biosynthesis of germacrene A carboxylic acid in chicory roots. Demonstration of a cytochrome P450 (+)-germacrene a hydroxylase and $\mathrm{NADP}^{+}$-dependent sesquiterpenoid dehydrogenase(s) involved in sesquiterpene lactone biosynthesis. Plant Physiol. 125: 1930-1940.

de Kraker JW, Franssen MC, Joerink M, de Groot A, et al. (2002). Biosynthesis of costunolide, dihydrocostunolide, and leucodin. Demonstration of cytochrome p450-catalyzed formation of the lactone ring present in sesquiterpene lactones of chicory. Plant Physiol. 129: 257-268.

de Proft M, van Stallen N and Veerle N (2003). Breeding and Cultivar Identification of Cichorium Intybus L. var. Foliosum Hegi. Proceedings of the Eucarpia Meeting on Leafy Vegetables Genetics and Breeding, Noordwijkerhout.

Estopa RA, Souza AM, Moura MCO, Botrel MCG, et al. (2006). Diversidade genética em populações naturais de candeia [Eremanthus erythropappus (DC.) MacLeish]. Sci. For. 70: 97-106.

Guo DL and Luo ZR (2006). Genetic relationships of some PCNA persimmons (Diospyros kaki Thunb.) from China and Japan revealed by SRAP analysis. Genet. Resour. Crop Ev. 53: 1597-1603.

Hauser TP, Jørgensen RB and Toneatto F (2012). Reduced sexual compatibility between cultivated and wild chicory and their $\mathrm{F}_{1}$ hybrids. Genet. Resour. Crop Ev. 59: 783-791.

Ivarsson E, Frankow-Lindberg BE, Andersson HK and Lindberg JE (2011). Growth performance, digestibility and faecal coliform bacteria in weaned piglets fed a cereal-based diet including either chicory (Cichorium intybus $\mathrm{L}$ ) or ribwort (Plantago lanceolata L) forage. Animal 5: 558-564.

Kiær LP, Felber F, Flavell A, Guadagnuolo R, et al. (2009). Spontaneous gene flow and population structure in wild and cultivated chicory, Cichorium intybus L. Genet. Resour. Crop Ev. 56: 405-419.

Kiers AM, Mes THM, Van der Meijden R and Bachmann K (1999). Morphologically defined Cichorium (Asteraceae) species reflect lineages based on chloroplast and nuclear (ITS) DNA data. Syst. Bot. 24: 645-659.

Kiers AM, Mes TH, van der Meijden R and Bachmann K (2000). A search for diagnostic AFLP markers in Cichorium species with emphasis on endive and chicory cultivar groups. Genome 43: 470-476.

Koch G and Jung C (1997). Phylogenetic relationships of industrial chicory varieties revealed by RAPDs and AFLPs. Agronomie 17: 323-333.

Li G and Quiros CF (2001). Sequence-related amplified polymorphism (SRAP), a new marker system based on a simple PCR reaction: its application to mapping and gene tagging in Brassica. Theor. Appl. Genet. 103: 455-461.

Lucchin M, Varotto S, Barcaccia G, Parrini P, et al (2008). Chicory and Endive. Vegetables. Springer New York, New York.

Martos V, Royo C, Rharrabti Y and Garcia del Moral LF (2005). Using AFLPs to determine phylogenetic relationships and genetic erosion in durum wheat cultivars released in Italy and Spain throughout the 20th century. Field Crop. Res. 91: 107-116.

Moura EF and de Oliveira MS (2012). Genetic diversity in a germplasm bank of Oenocarpus mapora (Arecaceae). Genet. Mol. Res. 11: 4008-4018.

Nandagopal S and Kumari BDR (2007). Phytochemical and antibacterial studies of chicory (Cichorium intybus L.) - a multipurpose medicinal plant. Adv. Biol. Res. 1: 17-21.

Nei M (1973). Analysis of gene diversity in subdivided populations. Proc. Natl. Acad. Sci. U. S. A. 70: 3321-3323.

Roldán-Ruiz I, Dendauw J, Van Bockstaele E and Depicker A (2000). AFLP markers reveal high polymorphic rates in ryegrasses (Lolium spp.). Mol. Breed. 6: 125-134.

Sarwat M, Das S and Srivastava PS (2008). Analysis of genetic diversity through AFLP, SAMPL, ISSR and RAPD markers in Tribulus terrestris, a medicinal herb. Plant Cell Rep. 27: 519-528.

Singh R, Sharma P, Varshney RK, Sharma SK, et al. (2008). Chickpea improvement: role of wild species and genetic markers. Biotechnol. Genet. Eng. Rev. 25: 267-313.

Sørensen BS, Kiaer LP, Jorgensen RB and Hauser TP (2007). The temporal development in a hybridizing population of wild and cultivated chicory (Cichorium intybus L.). Mol. Ecol. 16: 3292-3298.

Sulas L (2004). Forage chicory: A valuable crop for Mediterranean environments. Cahiers Options Mediterranéennes. 62: $137-140$.

Ullah I, Iram A, Iqbal MZ, Nawaz M, et al. (2012). Genetic diversity analysis of Bt cotton genotypes in Pakistan using simple sequence repeat markers. Genet. Mol. Res. 11: 597-605.

Van Cutsem P, du Jardin P, Boutte C, Beauwens T, et al. (2003). Distinction between cultivated and wild chicory gene pools using AFLP markers. Theor. Appl. Genet. 107: 713-718.

Vermeulen A, Desprez B, Lancelin D and Bannerot H (1994). Relationships among Cichorium species and related genera as determined by analysis of mitochondrial RFLPs. Theor. Appl. Genet. 88: 159-166. 